\title{
ANALISA KEKUATAN TARIK PADA SAMBUNGAN LAS BATERAI TERHADAP KEKUATAN ARUS LISTRIK BATERAI
}

\section{(ANALYSIS ON TENSILE STRENGTH OF CONNECTIONS BATTERY WELDING ON ELECTRICAL POWER CURRENT BATTERY)}

\author{
Sulharman ${ }^{1}$, Sudirman $^{2}$ \\ ${ }^{1}$ Mahasiswa Pasca Sarjana Teknik Mesin \\ Institut Teknologi Sepuluh Nopember \\ E-mail : sulharman11@mhs.me.its.ac.id \\ ${ }^{2}$ Politeknik Negeri Samarinda \\ E-mail : sudirman-polnes@ilmci.com
}

Naskah diterima 28 September 2012, disetujui 30 Nopember 2012

\begin{abstract}
ABSTRAK
Penelitian analisa kekuatan tarik pada sambungan las baterai terhadap kekuatan arus listrik baterai telah dilakukan.Tujuannya adalah untuk mengetahui kekuatan tarik sambungan las yang menggunakan las baterai dengan variabel arus baterai, ketebalan dan diameter bahan uji. Metode penelitian yang dilakukan, meliputi : (1) merakit las baterai (terdiri dari 3 buah baterai) dengan arus total yang diinginkan adalah $60 \mathrm{~A}, 80 \mathrm{~A}$ dan 120 A, (2) merangkai pengisian baterai dan stang las positif dan negatif, (3) pengelasan pada besi plat dengan tebal $4 \mathrm{~mm}, 6 \mathrm{~mm}$ dan $8 \mathrm{~mm}$ dengan arus $60 \mathrm{~A}, 80 \mathrm{~A}$ dan $120 \mathrm{~A}$, (4) pada besi batang diameter $8 \mathrm{~mm}, 10 \mathrm{~mm}$, dan $12 \mathrm{~mm}$ dengan arus $60 \mathrm{~A}, 80 \mathrm{~A}$ dan $120 \mathrm{~A}$. Hasil penelitian menunjukkan bentuk besi spesimen, kuat arus alat las dan ketebalan/diameter berpengaruh signifikan terhadap tegangan tarik spesimen hasil pengelasan dengan alat las baterai. Perlakuan terbaik untuk batang bulat adalah dengan arus 60 A pada diameter $8 \mathrm{~mm}$ menghasilkan kuat tarik sebesar $11,65 \mathrm{~kg} / \mathrm{mm}^{2}$. Perlakuan terbaik untuk plat adalah dengan arus $80 \mathrm{~A}$ pada tebal plat $8 \mathrm{~mm}$ menghasilkan kuat tarik sebesar $38,2 \mathrm{~kg} / \mathrm{mm}^{2}$. Dari hasil perhitungan ekonomi, biaya investasi dan operasional pembuatan alat, las baterai lebih murah dibandingkan las inventer dan las dinamo. Sedangkan biaya pengelasan per meter las baterai dan las inverter sama sebesar Rp.135.000-Rp.140.000, untuk las dinamo Rp.270.000-Rp.285.000. Namun keterbatasan las baterai tidak dapat diatur besar kecil arus baterainya.
\end{abstract}

Kata kunci : Las baterai, kuat tarik, arus listrik 


\begin{abstract}
Research analysis of the tensile strength of the weld on the battery to power an electric current battery has been done. The goal is to determine the tensile strength of welded joints using welding batteries with a variable flow battery, the thickness and diameter of the test material. Research methodology, including: (1) assemble welding battery (battery consists of 3 pieces) with the desired total current is $60 \mathrm{~A}, 80 \mathrm{~A}$ and $120 \mathrm{~A}$, (2) arranging charging the battery and welding handle bar positive and negative, (3) welding on iron plate with thickness $4 \mathrm{~mm}, 6 \mathrm{~mm}$ and $8 \mathrm{~mm}$ with a current 60 $A, 80 \mathrm{~A}$ and $120 \mathrm{~A}$, (4) on an iron rod diameter $8 \mathrm{~mm}, 10 \mathrm{~mm}$, and $12 \mathrm{~mm}$ with a current $60 \mathrm{~A}, 80 \mathrm{~A}$ and $120 \mathrm{~A}$. The results showed the shape of specimens of iron, welding tools and strong currents thickness / diameter significantly influence the tensile specimens welded with welding tools batteries. The best treatment to iron rod the current round is $60 \mathrm{~A}$ at $8 \mathrm{~mm}$ diameter tensile yield amounted to $11.65 \mathrm{~kg} / \mathrm{mm} 2$. The best treatment for the current iron plate is $80 \mathrm{~A}$ at $8 \mathrm{~mm}$ thick plate produce a tensile strength of $38.2 \mathrm{~kg} / \mathrm{mm} 2$. From the calculation of economic, investment and operational costs-making tools, welding batteries cheaper than welding inventer and welding dynamo. However, welding batteries can not be regulated the size of the battery current.
\end{abstract}

Keywords : Welding battery, tensile strength, electric current.

\title{
PENDAHULUAN
}

Sumber daya energi saat ini mengalami krisis, khususnya listrik. Disisi lain bengkel las selama ini menggunakan listrik dari PLN dan menggunakan generator listrik untuk mengelas. Pengelasan (welding) adalah suatu cara untuk menyambung benda padat dengan cara mencairkannya melalui pemanasan (Wiryosumarto, 2000 ).

Penggunaan listrik PLN minimal dibutuhkan daya sebesar 5500 watt, termasuk tarif industri (usaha) sehingga biaya per kwh cukup tinggi. Selain itu untuk pemasangan baru, sekarang sudah tidak ada lagi kalaupun ada masih menunggu antrian yang cukup lama. Sedangkan menggunakan generator listrik paling tidak sebesar $7 \mathrm{KV}$ dengan biaya kurang lebih Rp. 30.000.000,- dan memerlukan bahan bakar minyak.

Dari uraian di atas baik menggunakan listrik PLN maupun generator listrik dibutuhkan biaya investasi dan biaya operasional yang cukup besar, sehingga menyebabkan ongkos pengelasan juga menjadi tinggi.

Joko Santoso (2006) dalam tugas akhirnya pengaruh arus pengelasan terhadap kekuatan tarik dan ketangguhan las smaw dengan elektroda E7018 menyimpulkan bahwa dengan variasi arus pengelasan terjadi perubahan struktur akibat pendinginan sehingga berpengaruh terhadap kekuatan bahan yaitu terjadi peningkatan terhadap raw materials.

Dedi Priadi dan Selvianus M (2007) dalam penelitiannya mengenai pengaruh besarnya arus listrik terhadap distribusi kekerasan, struktur mikro, dan kekuatan impak pada baja karbon rendah menyebutkan bahwa arus pengelasan yang meningkat akan meningkatkan ukuran butir sehingga menurunkan ketangguhan logam terhadap perpatahan. Semakin halus butir yang terbentuk semakin 
ulet logam lasan atau sebaliknya semakin kasar butir yang terbentuk maka semakin getas logam lasan.

Fenoria Putri (2009) melalui penelitian pengaruh besar arus listrik dan panjang busur api terhadap hasil pengelasan menunjukkan bahwa panjang pendeknya busur berpengaruh juga dengan kekuatan dan kampuh hasil pengelasan.

Sedangkan Fenoria Putri (2010) melalui penelitian analisa pengaruh variasi kuat arus dan jarak pengelasan terhadap kekuatan tarik, sambungan las baja karbon rendah dengan elektroda 6013 didapat bahwa dengan menggunakan arus $70 \mathrm{~A}-110 \mathrm{~A}$ dengan jarak kampuh $1 \mathrm{~mm}$ dan 2 $\mathrm{mm}$, diperoleh arus $110 \mathrm{~A}$ dengan jarak kampuh $1 \mathrm{~mm}$ yang memiliki kekuatan tarik maksimum yaitu 507,33 $\mathrm{N} / \mathrm{mm}^{2}$. Makin besar arus dan makin besar jarak pengelasan maka makin lebar daerah sambungan las (weldment) yang terjadi.

Rancang bangun mesin las listrik baterai merupakan alternatif yang sebagian bengkel kecil banyak menggunakannya. Namun hasil pengelasan yang dilakukan perlu diketahui kekuatan sambungannya dengan uji tarik. Karena pengelasan dengan las baterai ini pengaturan arus listriknya tidak bisa diatur seperti layaknya las dengan menggunakan listrik PLN atau generator listrik. Oleh karena itu perlu dilakukan penelitian terhadap kekuatan sambungan las dengan variabel arus baterai terhadap diameter bahan uji dan tebal bahan uji. Dalam penelitian ini las baterai yang digunakan sama dengan las baterai yang digunakan di bengkel-bengkel.

Berdasarkan permasalahan tersebut di atas, tujuan dari penelitian ini adalah untuk mengetahui kekuatan tarik sambungan las yang menggunakan las baterai dengan variabel arus baterai, ketebalan dan diameter bahan uji.

\section{BAHAN DAN METODA Bahan dan alat}

Bahan yang digunakan pada penelitian ini adalah plat besi dengan tebal $4 \mathrm{~mm}, 6 \mathrm{~mm}$, dan $8 \mathrm{~mm}$. Batang bulat besi dengan diamater $8 \mathrm{~mm}, 10$ $\mathrm{mm}$ dan $12 \mathrm{~mm}$ serta elektroda las.

Sedangkan alat yang digunakan adalah baterai $100 \mathrm{~A}$ (1 buah), baterai $120 \mathrm{~A}$ (3 buah), baterai $50 \mathrm{~A}$ (1 buah), baterai $70 \mathrm{~A}$ ( 2 buah), dioda $50 \mathrm{~A}$, trafo $20 \mathrm{~A}$, pengukur amper, pengukur voltase, stang las, pendingin, saklar, kabel, tang, obeng, cutter, sketmat, avometer, topeng las dan sarung tangan las.

Pelaksanaan penelitian dilakukan di laboratorium pengelasan Politeknik Negeri Samarinda, JI. Ciptomangun kusumo Kampus Gunung Lipan Samarinda.

\section{Metode}

Tahapan proses penyelesai an penelitian adalah sebagai berikut; merakit mesin las baterai yaitu dengan cara merakit trafo (input 220 volt output 36 volt), dioda (dihubungkan secara seri) dan direkatkan pada pendingin (untuk mendinginkan dioda). Pasang pengukur amper dan voltase serta rangkai tiga baterai secara seri kemudian pasang stang las (positif dan negatif) pada terminal baterai. Kemudian melakukan pengelasan pada benda uji (plat besi dan batang bulat besi) serta menguji hasil pengelasan tersebut dengan alat uji tarik. Lebih jelasnya rangkaian las baterai ditunjukkan pada Gambar 1. 


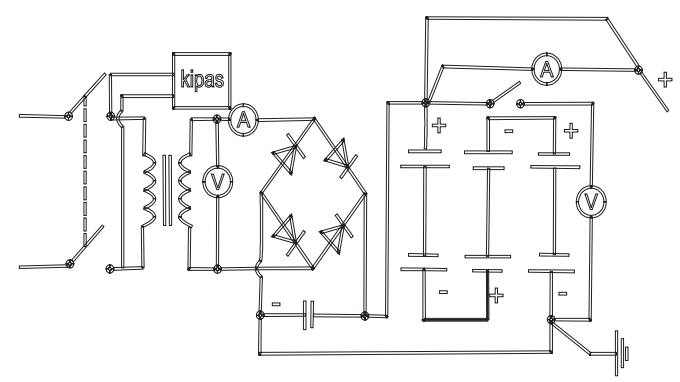

Gambar 1. Rangkaian las baterai (Suparno, Hariadi dan Imam, 2009)

\section{Rancangan Percobaan}

Pengelasan pada benda uji dengan diameter $8 \mathrm{~mm}, 10 \mathrm{~mm}$ dan 12 $\mathrm{mm}$, plat dengan tebal $4 \mathrm{~mm}, 6 \mathrm{~mm}$ dan $8 \mathrm{~mm}$. Dengan variasi arus masing-masing $60 \mathrm{~A}, 80 \mathrm{~A}, 120 \mathrm{~A}$. Masing-masing arus dan ketebalan atau diameter dilakukan 2 kali pengelasan. Hasil pengelasan dianalisa kekuatan sambungannya, dengan uji tarik pada masing-masing benda uji.

\section{Pengujian}

Setelah pengelasan pada benda uji, maka dilakukan uji tarik dengan menggunakan alat uji tarik terhadap benda uji kemudian dicatat hasil uji tariknya. Pembentukan benda uji sesuai standar pengujian tarik ASTM (American Standard Testing Material) seperti pada Gambar 2 dan 3.
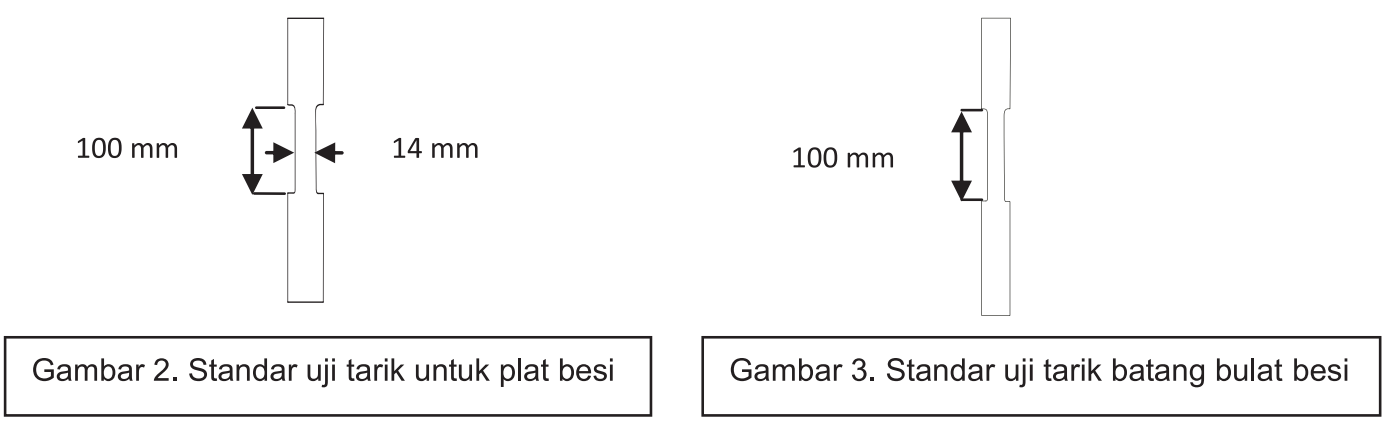

\section{HASIL DAN PEMBAHASAN}

Hasil pengujian tarik pada batang bulat besi dan plat besi terhadap arus baterai diperlihatkan pada Tabel 1 dan Tabel 2.

Tabel 1. Hasil pengujian tarik batang bulat besi terhadap arus baterai

\begin{tabular}{|c|c|c|c|c|c|}
\hline $\begin{array}{c}\text { Arus } \\
\text { I } \\
(\text { amper })\end{array}$ & $\begin{array}{c}\text { Diameter } \\
\varnothing \\
(\mathrm{mm})\end{array}$ & $\begin{array}{c}\text { Tegangan } \\
\text { Maksimum } \\
\begin{array}{c}\tau \\
\left(\mathrm{kg} / \mathrm{mm}^{2}\right)\end{array}\end{array}$ & $\begin{array}{c}\text { Panjang } \\
\text { awal } \\
\text { lo } \\
(\mathrm{mm})\end{array}$ & $\begin{array}{c}\text { Rata-rata } \\
\text { Tegangan } \\
\text { maksimum } \\
\left(\mathrm{kg} / \mathrm{mm}^{2}\right)\end{array}$ & $\begin{array}{c}\text { Foto } \\
\text { Hasil Uji Tarik }\end{array}$ \\
\hline 60 & 8 & 13,5 & 100 & 11,65 & \\
\hline & 8 & 9,8 & 100 & & \\
\hline
\end{tabular}




\begin{tabular}{|c|c|c|c|c|c|}
\hline $\begin{array}{c}\text { Arus } \\
\text { I } \\
\text { ( amper ) }\end{array}$ & $\begin{array}{c}\text { Diameter } \\
\varnothing \\
(\mathrm{mm})\end{array}$ & $\begin{array}{c}\text { Tegangan } \\
\text { Maksimum } \\
\tau \\
\left(\mathrm{kg} / \mathrm{mm}^{2}\right)\end{array}$ & $\begin{array}{c}\text { Panjang } \\
\text { awal } \\
\text { lo } \\
\text { (mm) }\end{array}$ & $\begin{array}{c}\text { Rata-rata } \\
\text { Tegangan } \\
\text { maksimum } \\
\left(\mathrm{kg} / \mathrm{mm}^{2}\right)\end{array}$ & $\begin{array}{c}\text { Foto } \\
\text { Hasil Uji Tarik }\end{array}$ \\
\hline & 10 & 10,7 & 100 & \multirow{2}{*}{10,7} & \\
\hline & 10 & 10,7 & 100 & & \\
\hline & 12 & 22,3 & 100 & \multirow{2}{*}{18,55} & \\
\hline & 12 & 14,8 & 100 & & \\
\hline \multirow[t]{6}{*}{80} & 8 & 10 & 100 & \multirow{2}{*}{12,5} & \\
\hline & 8 & 15 & 100 & & \\
\hline & 10 & 17,5 & 100 & \multirow{2}{*}{17,35} & \\
\hline & 10 & 17,2 & 100 & & \\
\hline & 12 & 38 & 100 & \multirow{2}{*}{36,5} & \\
\hline & 12 & 35 & 100 & & $z$ \\
\hline \multirow[t]{6}{*}{120} & 8 & 8 & 100 & \multirow{2}{*}{11,15} & \\
\hline & 8 & 14,3 & 100 & & \\
\hline & 10 & 29,2 & 100 & \multirow{2}{*}{29,6} & \\
\hline & 10 & 30 & 100 & & \\
\hline & 12 & 50 & 100 & \multirow{2}{*}{41,4} & \\
\hline & 12 & 32,8 & 100 & & \\
\hline
\end{tabular}

Tabel 2. Hasil pengujian tarik plat besi terhadap arus baterai

\begin{tabular}{|c|c|c|c|c|c|}
\hline $\begin{array}{c}\text { Arus } \\
\text { I } \\
(\text { amper })\end{array}$ & $\begin{array}{c}\text { Tebal } \\
\mathrm{t} \\
(\mathrm{mm})\end{array}$ & $\begin{array}{c}\text { Tegangan } \\
\text { Maksimum } \\
\mathrm{T} \\
\left(\mathrm{kg} / \mathrm{mm}^{2}\right)\end{array}$ & $\begin{array}{c}\text { Panjang } \\
\text { awal } \\
\text { lo } \\
(\mathrm{mm})\end{array}$ & $\begin{array}{c}\text { Rata-rata } \\
\text { Tegangan } \\
\text { maksimum } \\
\left(\mathbf{k g} / \mathrm{mm}^{2}\right)\end{array}$ & $\begin{array}{c}\text { Foto Hasil Uji } \\
\text { Tarik }\end{array}$ \\
\hline 60 & 4 & 18,5 & 100 & \multirow{2}{*}{21,1} & \\
\hline & 4 & 23,7 & 100 & & \\
\hline
\end{tabular}




\begin{tabular}{|c|c|c|c|c|c|}
\hline $\begin{array}{c}\text { Arus } \\
\text { I } \\
\text { (amper) }\end{array}$ & $\begin{array}{c}\text { Tebal } \\
\mathbf{t} \\
(\mathrm{mm})\end{array}$ & $\begin{array}{c}\text { Tegangan } \\
\text { Maksimum } \\
\tau \\
\left(\mathrm{kg} / \mathrm{mm}^{2}\right)\end{array}$ & $\begin{array}{c}\text { Panjang } \\
\text { awal } \\
\text { lo } \\
\text { (mm) }\end{array}$ & $\begin{array}{c}\text { Rata-rata } \\
\text { Tegangan } \\
\text { maksimum } \\
\left(\mathrm{kg} / \mathrm{mm}^{2}\right)\end{array}$ & $\begin{array}{c}\text { Foto Hasil Uji } \\
\text { Tarik }\end{array}$ \\
\hline & 6 & 29,1 & 100 & \multirow{2}{*}{29,1} & \\
\hline & 6 & 29,1 & 100 & & \\
\hline & 8 & 37 & 100 & \multirow{2}{*}{38,2} & \\
\hline & 8 & 39,4 & 100 & & \\
\hline \multirow[t]{6}{*}{80} & 4 & $12(0)$ & 100 & \multirow{2}{*}{11} & \\
\hline & 4 & 10 & 100 & & \\
\hline & 6 & 28,7 & 100 & \multirow{2}{*}{28,7} & \\
\hline & 6 & 28,7 & 100 & & \\
\hline & 8 & 38 & 100 & \multirow[b]{2}{*}{39,65} & \\
\hline & 8 & 41,3 & 100 & & \\
\hline \multirow[t]{6}{*}{120} & 4 & 23,7 & 100 & \multirow{2}{*}{18,3} & \\
\hline & 4 & 12,9 & 100 & & \\
\hline & 6 & 29 & 100 & \multirow{2}{*}{28} & \\
\hline & 6 & 27 & 100 & & \\
\hline & 8 & 41 & 100 & \multirow{2}{*}{40,5} & \\
\hline & 8 & 40 & 100 & & \\
\hline
\end{tabular}

\section{Analisa pada spesimen besi batang}

bulat

Tabel 3. merupakan Anova yang mengurai keragaman tegangan kedalam faktor-faktor yang memberikan kontribusi pada hasil akhir. Nilai P (Probability Value) menguji signifikansi (kepentingan/perbedaan/nyata) secara statistik dari masing-masing faktor. Ada 2 nilai $P$ ( $P$-Value) yang kurang dari 0.05 , yakni faktor kuat arus dan faktor diameter. Keduanya memiliki pengaruh yang signifikan terhadap nilai tegangan tarik pada tingkat kepercayaan $95 \%$. 
Tabel 3. Analisa varian tegangan tarik terhadap arus dan diamater untuk batang bulat

\begin{tabular}{|c|c|c|c|c|c|}
\hline Source & Sum of Squares & $\mathrm{Df}$ & Mean Square & F-Ratio & $p$-Value \\
\hline MAIN EFFECTS & & & & & \\
\hline A:Arus & 578.188 & 2 & 289.094 & 6.38 & 0.0117 \\
\hline B:Diameter & 1275.42 & 2 & 637.711 & 14.07 & 0.0006 \\
\hline RESIDUAL & 589.194 & 13 & 45.3226 & & \\
\hline TOTAL (CORRECTED) & 2442.8 & 17 & & & \\
\hline
\end{tabular}

Hasil yang dilakukan dengan menggunakan multi range test tegangan tarik terhadap arus untuk batang bulat menunjukkan bahwa perbedaan signifikan terjadi antara kuat arus 60 A dan 80 A (Df-8.5333), antara kuat arus $60 \mathrm{~A}$ dan $120 \mathrm{~A}$ (Df13.75). Sedangkan antara arus $80 \mathrm{~A}$ dan 120 A (Df-5.2166) tidak menunjukkan perbedaan yang signifikan atau arus alat las $80 \mathrm{~A}$ dan 120 A menghasilkan tegangan tarik yang sama saja dan untuk alasan ekonomis, diantara kedua ini dipilih yang 80 A untuk memperoleh hasil yang sama.

Sementara hasil uji lanjut untuk pengaruh diameter terhadap tegangan tarik untuk batang bulat menunjukkan bahwa perbedaan signifikan terjadi antara diameter $8 \mathrm{~mm}$ dan diameter 12 $\mathrm{mm}$ (Df-20.3833) dan antara diameter $10 \mathrm{~mm}$ dan $12 \mathrm{~mm}$ (Df-12.8833). Sedangkan antara diameter $8 \mathrm{~mm}$ dan $10 \mathrm{~mm}$ (Df-7.5) tidak menunjukan adanya perbedaan yang signifikan atau dengan kata lain penggunaan besi batang bulat baik $8 \mathrm{~mm}$ maupun $10 \mathrm{~mm}$ hanya akan menghasilkan tegangan tarik yang sama saja. Oleh karena itu jika hanya melihat tegangan tarik sambungan spesimen yang di las dengan alat ini penggunaan besi 10 $\mathrm{mm}$ tidak lebih kuat dibanding besi 8 $\mathrm{mm}$. Kalau diameter besi tidak mempengaruhi kekuatan konstruksi secara keseluruhan, penggunaan besi $8 \mathrm{~mm}$ dapat direkomendasikan dibanding besi $10 \mathrm{~mm}$.

Tabel 4. menunjukkan analisa uji regresi tegangan tarik terhadap arus dan diameter untuk batang bulat.

Tabel 4. menunjukkan hasil uji relasi antara tegangan tarik dengan kuat arus dan dengan diameter bahwa pada spesimen batang bulat hubungan antara arus dengan tegangan tarik adalah relatip lemah dengan koefisien korelasi $(r=0.46)$. Sebaliknya hubungan antara diameter dengan tegangan tarik adalah relatip kuat dengan koefisien korelasi $(r=0.71)$. 
Tabel 4. Analisa uji regresi tegangan tarik terhadap arus dan diamater untuk batang bulat

\begin{tabular}{|c|c|c|c|c|}
\hline $\begin{array}{l}\text { Keterangan: } \\
\text { Dependent variable } \\
\text { Independent variable }\end{array}$ & $\begin{array}{l}\text { Tegangan } \\
\text { Arus }\end{array}$ & & & \\
\hline Parameter & Estimate & Standard Error & T-Statistic & $p$-Value \\
\hline Intercept & 2.42262 & 9.34669 & 0.25916 & 0.7988 \\
\hline Slope & 0.21506 & 0.103639 & 2.07508 & 0.0545 \\
\hline
\end{tabular}

Analysis of Variance

\begin{tabular}{lccccc}
\hline \multicolumn{1}{c}{ Source } & Sum of Squares & Df & Mean Square & F-Ratio & p-Value \\
\hline Model & 518.007 & 1 & 518.007 & 4.31 & 0.0545 \\
Residual & 1924.8 & 16 & 120.3 & & \\
\hline Total ( Corr.) & 2442.8 & 17 & & & \\
\hline Correlation coefficient $=0.46093$ & & & & \\
R-squared $=21.2054$ percent & & & & \\
Standard error of Est. $=$ & 10.9681 & & & \\
\hline Keterangan : & Tegangan & & & \\
Dependent variable & $:$ Trus & & & \\
Independent variable & $:$ Arus & & & \\
\hline \multicolumn{1}{c}{ Parameter } & Estimate & Standard Error & T-Statistic & p-Value \\
\hline Intercept & -29.8972 & 12.6464 & -2.3641 & 0.0311 \\
Slope & 5.09583 & 1.2481 & 4.08286 & 0.0009 \\
\hline
\end{tabular}

Analysis of Variance

\begin{tabular}{lccccc}
\hline \multicolumn{1}{c}{ Source } & Sum of Squares & Df & Mean Square & F-Ratio & p- Value \\
\hline Model & 1246.44 & 1 & 1246.4 & 16.67 & 0.0009 \\
Residual & 1196.36 & 16 & 74.772 & & \\
\hline Total ( Corr.) & 2442.8 & 17 & & & \\
\hline Correlation coefficient $=$ 0.714318 & & & & \\
R-squared $=$ 51.025 percent & & & & \\
Standard error of Est. $=8.64712$ & &
\end{tabular}

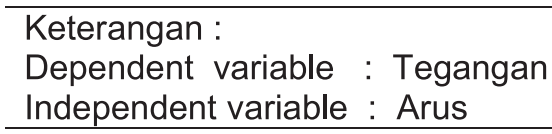

\begin{tabular}{lcccl}
\hline & & Standard & T & \\
Parameter & Estimate & Error & Statistic & p-Value \\
\hline Intercept & 2.42262 & 9.34669 & 0.25916 & 0.7988 \\
Slope & 0.21506 & 0.103639 & 2.07508 & 0.0545 \\
\hline
\end{tabular}

Analysis of Variance

\begin{tabular}{lcrrrr}
\hline Source & Sum of Squares & Df & Mean Square & F-Ratio & p-Value \\
\hline Model & 518.007 & 1 & 518.007 & 4.31 & 0.0545 \\
Residual & 1924.8 & 16 & 120.3 & & \\
\hline
\end{tabular}


dan dengan diameter bahwa pada spesimen batang bulat hubungan antara arus dengan tegangan tarik adalah relatip lemah dengan koefisien korelasi $(r=0.46)$. Sebaliknya hubungan antara diameter dengan tegangan tarik adalah relatip kuat dengan koefisien korelasi $(r=0.71)$.

Gambar 4. menunjukkan grafik tegangan tarik pada arus baterai 60 $\mathrm{A}, 80 \mathrm{~A}$,dan $120 \mathrm{~A}$ terhadap diameter besi $8 \mathrm{~mm}, 10 \mathrm{~mm}$, dan $12 \mathrm{~mm}$.

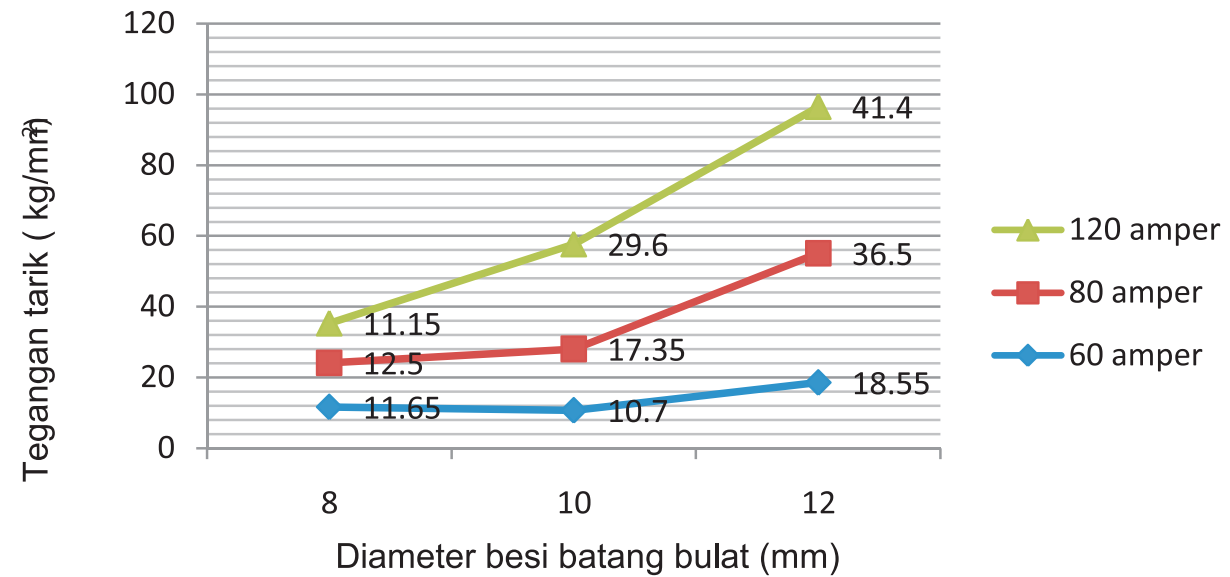

Gambar 4. Grafik tegangan tarik pada arus baterai $60 \mathrm{~A}, 80 \mathrm{~A}$ dan $120 \mathrm{~A}$ terhadap diamater besi $8 \mathrm{~mm}, 10 \mathrm{~mm}$, dan $12 \mathrm{~mm}$

Pada Gambar 4. memperlihatkan arus baterai $60 \mathrm{~A}, 80 \mathrm{~A}$ dan $120 \mathrm{~A}$ terhadap tegangan tarik pada pengelasan diameter besi $8 \mathrm{~mm}, 10$ $\mathrm{mm}$ dan $12 \mathrm{~mm}$. Pada diameter besi $10 \mathrm{~mm}$ tegangan tarik memperlihatkan penurunan tegangan tarik (dibawah $11,65 \mathrm{~kg} / \mathrm{mm}^{2}$ ) hal ini dikarenakan adanya penurunan arus dari baterai (arus tidak stabil lagi dikarenakan pemakaian proses pengelasan sebelumnya), sehingga arus belum cukup kuat untuk mencairkan sambungan. Hasil uji tarik pada arus 60 A diameter $8 \mathrm{~mm}=11,65 \mathrm{~kg} / \mathrm{mm}^{2}$, diameter $10 \mathrm{~mm}=10,7 \mathrm{~kg} / \mathrm{mm}^{2}$ dan diameter $12 \mathrm{~mm}=18,55 \mathrm{~kg} / \mathrm{mm}^{2}$. Hasil uji tarik pada arus 80 A diameter $8 \mathrm{~mm}$ $=12,5 \mathrm{~kg} / \mathrm{mm}^{2}$, diameter $10 \mathrm{~mm}=$ $17,35 \mathrm{~kg} / \mathrm{mm}^{2}$ dan diameter $12 \mathrm{~mm}=$ $36,5 \mathrm{~kg} / \mathrm{mm}^{2}$. Hasil uji tarik pada arus 120 A diameter $8 \mathrm{~mm}=11,15 \mathrm{~kg} / \mathrm{mm}^{2}$, diameter $10 \mathrm{~mm}=29,6 \mathrm{~kg} / \mathrm{mm}^{2}$ dan diameter $12 \mathrm{~mm}=41,4 \mathrm{~kg} / \mathrm{mm}^{2}$. Tabel 5. Menunjukkan letak patahan pada specimen batang bulat.

Tabel 5. Letak patahan pada spesimen batang bulat

\begin{tabular}{c|c|c|c|c}
\hline \multicolumn{5}{c}{ Diamater } \\
\hline \multirow{4}{*}{ Arus } & & 8 & 10 & 12 \\
\cline { 2 - 5 } & 60 & $\mathrm{~L}$ & $\mathrm{D}$ & $\mathrm{D}$ \\
\cline { 2 - 5 } & 80 & $\mathrm{~L}$ & $\mathrm{D}$ & $\mathrm{D}$ \\
\cline { 2 - 5 } & 120 & $\mathrm{~L}$ & $\mathrm{D}$ & $\mathrm{D}$ \\
\hline
\end{tabular}

Keterangan;

$L$; patahan di luar bidang las, $D$; patahan di dalam bidang las 
Dari hasil visual sisa patahan, hanya pada diameter $8 \mathrm{~mm}$ yang patahannya berada di luar bidang las dan ini mengindikasikan hasil penyambungan las baterai lebih kuat dibanding pada diameter $10 \mathrm{~mm}$ dan $12 \mathrm{~mm}$. Hasil ini sejalan dengan hasil uji signifikansi tegangan tarik yang menunjukkan bahwa kuat arus 80 A dan 120 A tidak terlalu signifikan terhadap kuat tarik.

Pengelasan pada besi batang bulat cocok untuk pengelasan yang menggunakan diameter yang tidak terlalu besar (tidak lebih dari $8 \mathrm{~mm}$ ), karena arus yang dihasilkan tidak dapat menembus bahan, ada pembekuan di dalam sambungan yang tidak merata, hal ini juga disebabkan arus yang tidak bisa konstan seperti las listrik sehingga mempengaruhi kekuatan sambungan.

\section{Analisa pada spesimen plat besi}

Tabel 6. merupakan Anova yang mengurai keragaman tegangan kedalam faktor-faktor yang memberikan kontribusi pada hasil akhir. Nilai $\mathrm{P}$ (Probability Value) menguji signifikansi (kepentingan/perbedaan/nyata) secara statistik dari masing-masing faktor. Karena ada 1 nilai $\mathrm{P}$ ( $P$-Value) yang kurang dari 0.05, maka faktor tebal memiliki pengaruh yang signifikan secara statistik terhadap nilai tegangan tarik pada tingkat kepercayaan 95\%. Dalam hal ini faktor kuat arus tidak berpengaruh secara signifikan terhadap sifat tegangan tarik spesimen yang dilas dengan alat ini.

Tabel 6. Analisa varian tegangan tarik terhadap arus dan tebal plat

\begin{tabular}{lrrrrr}
\hline Source & Sum of Squares & Df & Mean Square & F-Ratio & p-Value \\
\hline MAIN EFFECTS & & & & & \\
A:Arus & 31.1033 & 2 & 15.5517 & 1.20 & 0.3335 \\
B:Tebal_Plat & 1539.97 & 2 & 769.985 & 59.24 & 0.0000 \\
& & & & & \\
RESIDUAL & 168.972 & 13 & 12.9978 & & \\
\hline TOTAL (CORRECTED) & 1740.05 & 17 & & & \\
\hline All F-ratios are & 17 &
\end{tabular}

All F-ratios are based on the residual mean square error.

Hasil uji lanjut dengan menggunakan multi range test tegangan tarik terhadap tebal untuk plat menunjukkan bahwa perbedaan signifikan terjadi antar ketebalan plat di semua level. Ketebalan $4 \mathrm{~mm}$ berbeda dengan ketebalan $6 \mathrm{~mm}$ (Df-11.8), ketebalan $6 \mathrm{~mm}$ berbeda dengan ketebalan $8 \mathrm{~mm}$ (Df-10.85), apalagi antara ketebalan $4 \mathrm{~mm}$ dengan ketebalan $8 \mathrm{~mm}$ (Df-22.65).
Karena hasil Anova tidak menunjukkan signifikansi pengaruh dari arus terhadap tegangan tarik maka uji lanjut sudah tidak diperlukan lagi. Tabel 7. menunjukkan analisa uji regresi tegangan tarik terhadap arus dan tebal untuk plat. Tabel 8. Menunjukkan letak patahan pada specimen plat besi.

Tabel 7. Analisa uji regresi tegangan tarik terhadap arus dan tebal pelat

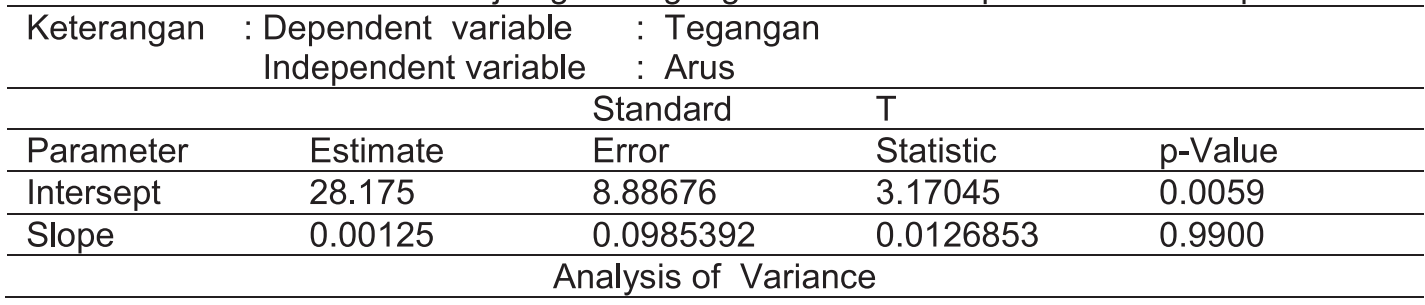




\begin{tabular}{|c|c|c|c|c|c|}
\hline Source & Sum of Squares & Df & Mean Square & F-Ratio & $p$-Value \\
\hline Model & 0.0175 & 1 & 0.0175 & 0.00 & 0.9900 \\
\hline Residual & 1740.03 & 16 & 108.752 & & \\
\hline Total (Corr) & 1740.05 & 17 & & & \\
\hline \multicolumn{6}{|c|}{$\begin{array}{l}\text { Correlation coefficient }=0.00317131 \\
R \text {-squared }=0.00100572 \text { percent } \\
\text { Standard error of Est. }=10.4284\end{array}$} \\
\hline \multirow[t]{2}{*}{ Keterangan } & \multicolumn{2}{|c|}{$\begin{array}{l}\text { Dependent variable } \\
\text { Independent variable }\end{array}$} & \multicolumn{2}{|c|}{$\begin{array}{l}\text { : Tegangan } \\
: \text { Tebal pelat }\end{array}$} & \\
\hline & & Standard & \multicolumn{2}{|l|}{$T$} & \\
\hline Parameter & Estimate & \multirow{2}{*}{$\frac{\text { Error }}{3.18098}$} & \multicolumn{2}{|l|}{ Statistic } & $p$-Value \\
\hline Intersept & -5.69167 & & \multicolumn{2}{|l|}{-1.78928} & 0.0925 \\
\hline Slope & 5.6625 & 0.511556 & 11.0692 & & 0.0000 \\
\hline \multicolumn{6}{|c|}{ Analysis of Variance } \\
\hline Source & Sum of Squares & $\mathrm{Df}$ & Mean Square & F-Ratio & p-Value \\
\hline Model & 539.07 & 1 & 1539.07 & 122.53 & 0.0000 \\
\hline Residual & 200.977 & 16 & 12.5611 & & \\
\hline Total (Corr) & 1740.05 & 17 & & & \\
\hline $\begin{array}{l}\text { Correlation c } \\
R \text {-squared = } \\
\text { Standard erro }\end{array}$ & $\begin{array}{l}\text { fficient }=0.940478 \\
4499 \text { percent } \\
\text { f Est. }=3.54416\end{array}$ & & & & \\
\hline
\end{tabular}

Hasil uji relasi antara tegangan tarik dengan kuat arus dan dengan diameter menunjukkan bahwa pada spesimen besi plat hubungan antara arus dengan tegangan tarik adalah relatif sangat lemah dengan koefisien korelasi $(r=0.003)$. Sebaliknya hubungan antara diameter dengan tegangan tarik adalah relatif sangat kuat dengan koefisien korelasi $(r=$ 0.94).

Gambar 5. menunjukkan grafik tegangan tarik pada arus baterai $60 \mathrm{~A}$, $80 \mathrm{~A}$,dan 120 A terhadap tebal plat besi $4 \mathrm{~mm}, 6 \mathrm{~mm}$, dan $8 \mathrm{~mm}$.

Pada Gambar 5. memperlihatkan arus baterai $60 \mathrm{~A}, 80 \mathrm{~A}$, dan $120 \mathrm{~A}$ terhadap tegangan tarik pada pengelasan plat besi $4 \mathrm{~mm}, 6 \mathrm{~mm}$ dan $8 \mathrm{~mm}$. Terlihat tegangan tarik maksimum meningkat, arus baterai cukup stabil. Sehingga diperoleh hasil uji tarik pada arus 60 A tebal $4 \mathrm{~mm}=$ $21,1 \mathrm{~kg} / \mathrm{mm}^{2}$, tebal $6 \mathrm{~mm}=29,1$ $\mathrm{kg} / \mathrm{mm}^{2}$ dan tebal $8 \mathrm{~mm}=38,2$ $\mathrm{kg} / \mathrm{mm}^{2}$. Hasil uji tarik pada arus $80 \mathrm{~A}$ tebal $4 \mathrm{~mm}=11 \mathrm{~kg} / \mathrm{mm}^{2}$, tebal $6 \mathrm{~mm}=$ $28,7 \mathrm{~kg} / \mathrm{mm}^{2}$ dan tebal $8 \mathrm{~mm}=39,65$ $\mathrm{kg} / \mathrm{mm}^{2}$. Hasil uji tarik pada arus 120 A tebal $4 \mathrm{~mm}=18,3 \mathrm{~kg} / \mathrm{mm}^{2}$, tebal 6 $\mathrm{mm}=28 \mathrm{~kg} / \mathrm{mm}^{2}$ dan tebal $8 \mathrm{~mm}=$ $40,5 \mathrm{~kg} / \mathrm{mm}^{2}$.

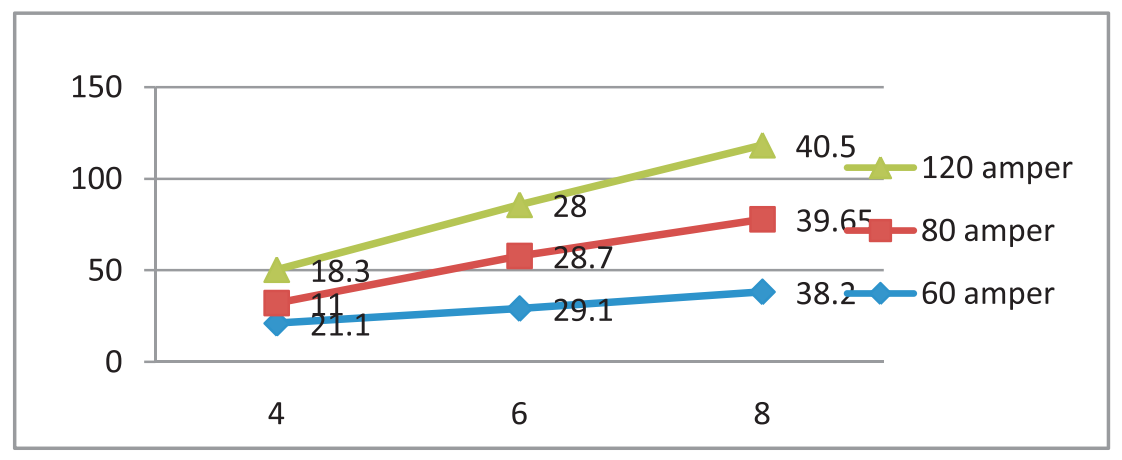

Gambar 5. Grafik tegangan tarik pada arus baterai $60 \mathrm{~A}, 80 \mathrm{~A}$, dan $120 \mathrm{~A}$ terhadap plat besi tebal $4 \mathrm{~mm}, 6 \mathrm{~mm}$, dan $8 \mathrm{~mm}$ 
Tabel 8. Letak patahan pada specimen plat besi.

\begin{tabular}{c|c|c|c|c}
\hline \multicolumn{5}{c}{} \\
\cline { 2 - 5 } Arus & 60 & 4 & 6 & 8 \\
\cline { 2 - 5 } (amper) & 80 & $\mathrm{~L}$ & $\mathrm{~L}$ & $\mathrm{~L}$ \\
\cline { 2 - 5 } & 120 & $\mathrm{~L}$ & $\mathrm{~L}$ & $\mathrm{~L}$ \\
\hline
\end{tabular}

\section{Keterangan;}

$L$; patahan di luar bidang las, $D$; patahan di dalam bidang las

Dari hasil visual sisa patahan, pada tebal 4, 6 dan $8 \mathrm{~mm}$ semua patahannya berada di luar bidang las dan ini mengindikasikan hasil penyambungan las baterai kuat.

Pengelasan pada besi plat, uji tarik dari berbagai arus dan tebal memperlihatkan patah diluar daerah las hal ini menunjukkan pengelasan baterai cukup kuat. Namun untuk besi plat yang lebih tebal lagi diperlukan arus yang lebih besar lagi sesuai dengan spesifikasi pengelasan.

\section{Analisa pengaruh bentuk besi (Batang bulat dan Plat)}

Tabel 9.memperlihatkan analisa uji regresi tegangan tarik terhadap arus dan tebal plat.

Tabel 9. Analisa uji regresi tegangan tarik terhadap arus dan tebal plat Analysis of Variance for Tegangan - Type III Sums of Squares

\begin{tabular}{llllll}
\hline Source & Sum of Squares & Df & Mean Squares & F-Ratio & p-Value \\
\hline MAIN EFFECTS & & & & & \\
\hline A: Bentuk Besi & 2299.1 & 1 & 2299.1 & 58.36 & 0.0000 \\
\hline B: Arus & 264.404 & 2 & 132.202 & 3.36 & 0.0494 \\
\hline C: Diameter & 2815.39 & 4 & 703.848 & 17.87 & 0.0000 \\
\hline RESIDUAL & 1103.05 & 28 & 39.3947 & & \\
\hline TOTAL (CORRECTED) & 4652.29 & 35 & & & \\
\hline
\end{tabular}

All F-ratios are based on the residual mean square error

Hasil uji secara keseluruhan menunjukan bahwa bentuk bahan, arus dan ketebalan atau diameter mempunyai pengaruh yang signifikan dengan tingkatan yang berbeda-beda (lemah/sedang/ kuat) terhadap hasil akhir tegangan tarik spesimen. Anova secara keseluruhan juga menunjukkan kuat arus yang paling lemah pengaruhnya $(p=0.0494)$ karena jika diambil dua desimal nilai signifikansinya sama dengan 0.05 , batas terendah penolakan Hipotesa nol $\left(\mathrm{H}_{0}\right)$. Tampak sangat nyata bahwa bentuk besi batang bulat dan plat memberikan hasil yang berbeda dengan hasil las plat $\left(38.32 \mathrm{~kg} / \mathrm{mm}^{2}\right)$ lebih kuat 3 kali lipat dari hasil las batang bulat $\left(10.7 \mathrm{~kg} / \mathrm{mm}^{2}\right)$.

\section{Tekno Ekonomi}

Untuk membuat las baterai diperlukan biaya investasi dan operasional sebagai berikut ; Baterai 70 amper 3 buah $=$ Rp. $670.000 \times 3=$ Rp.2.010.000,- (bisa kita gunakan amper baterai yang lebih tinggi), Dioda 4 buah = Rp. $15.000 \times 4=$ Rp.60.000,, Pendingin 1 buah = Rp. 100.000,-, Stang las $=$ Rp. 500.000,- , Trafo 20 amper = Rp. 500.000,- ,Daya listrik rumah cuma 450 watt (biaya 
pemakaian listrik/bulan murah) sehingga total $=$ Rp. $3.170 .000,-$

Untuk las inverter ; Inverter 1000 watt $=$ Rp.1.500.000, Daya listrik rumah 3500 watt $=$ Rp.10.000.000,(belum biaya pemakaian listrik / bulan) dengan total $=$ Rp. 11.500.000,-

Sedangkan untuk las dinamo (bahan bakar solar) : Dinamo = Rp.14.000.000,-, Mesin penggerak = Rp.4.000.000,- (belum biaya pemakaian solar / bulan ) sehingga total $=$ Rp. 18.000.000,-

Sedangkan biaya pengelasan per meter las baterai dan las inverter sama sebesar Rp.135.000Rp.140.000 karena menggunakan listrik PLN, untuk las dinamo Rp.270.000-Rp.285.000 karena menggunakan bahan bakar solar.

Dari perhitungan rincian biaya investasi dan operasional tersebut di atas, terlihat las baterai paling murah, tetapi memiliki kelemahan dari segi arus (tidak dapat diatur), selain itu pula las baterai mudah dibawa kemanamana.

\section{KESIMPULAN DAN SARAN}

Hasil pengelasan pada besi batang bulat cocok untuk pengelasan yang menggunakan diameter tidak terlalu besar (tidak lebih dari $8 \mathrm{~mm}$ ), karena arus yang dihasilkan tidak dapat menembus bahan, ada pembekuan di dalam sambungan yang tidak merata, hal ini juga disebabkan arus yang tidak bisa konstan seperti las listrik sehingga mempengaruhi kekuatan sambungan.

Hasil pengelasan pada besi plat, uji tarik dari berbagai arus dan tebal memperlihatkan patah diluar daerah las hal ini menunjukkan pengelasan baterai cukup kuat. Namun untuk besi plat yang lebih tebal lagi diperlukan arus yang lebih besar lagi sesuai dengan spesifikasi pengelasan.

Bentuk besi spesimen, kuat arus alat las dan ketebalan/diameter berpengaruh signifikan terhadap tegangan tarik spesimen hasil pengelasan dengan alat las baterai. Perlakuan terbaik untuk batang bulat adalah dengan arus $60 \mathrm{~A}$ pada diameter $8 \mathrm{~mm}$ menghasilkan kuat tarik sebesar $11,65 \mathrm{~kg} / \mathrm{mm}^{2}$. Perlakuan terbaik untuk plat adalah $80 \mathrm{~A}$ pada tebal plat $8 \mathrm{~mm}$ menghasilkan kuat tarik sebesar $38,2 \mathrm{~kg} / \mathrm{mm}^{2}$.

Dari segi investasi dan biaya operasional alat, las baterai paling murah (Rp.3.170.000,-) dibandingkan las inverter (Rp.11.500.000,-) dan las dinamo (Rp.18.000.000,-), Sedangkan biaya pengelasan per meter las baterai dan las inverter sama sebesar Rp.135.000-Rp.140.000, untuk las dinamo Rp.270.000Rp.285.000.Namun tidak dapat diatur besar kecilnya arus baterainya.

Pengelasan baterai cocok untuk kebutuhan pengelasan yang tidak menuntut persyaratan kekuatan sambungan secara khusus seperti pekerjaan kontruksi. Selain itu praktis untuk pekerjaan pembuatan pagar, teralis, pot bunga, dan body kendaraan.

Perlu dilakukan penelitian lebih lanjut mengenai pembuatan alat pengatur arus listrik baterai.

\section{UCAPAN TERIMA KASIH}

Penulis mengucapkan terima kasih kepada Balai Riset dan Standardisasi Industri Samarinda yang telah mendanai penelitian ini dan juga kepada dosen dan staf Laboratorium Manufaktur Politeknik Negeri Samarinda atas kerjasamanya dalam melakukan penelitian ini.

\section{DAFTAR PUSTAKA}

Fenoria Putri, 2009. Pengaruh Besar Arus Listrik Dan Panjang Busur Api Terhadap Hasil Pengelasan. Jurnal Austenit 
Volume 1, Nomor 02, Oktober 2009. Politeknik Negeri Sriwijaya.Palembang

Fenoria Putri, 2010. Analisa Pengaruh

Variasi Kuat Arus Dan Jarak Pengelasan Terhadap

Kekuatan Tarik, Sambungan

Las Baja Karbon Rendah

Dengan Elektroda 6013. Jurnal

Austenit Volume 2, Nomor

02.2010.Politeknik

Negeri

Sriwijaya.Palembang

Joko Santoso, 2006. Pengaruh Arus

Pengelasan Terhadap

Kekuatan Tarik Dan

Ketangguhan Las Smaw

Dengan Elektroda

E7018.Tugas Akhir. Fakultas

Teknik. Universitas Negeri

Semarang.
Priadi, D. dan Selvinus M, 2007.Studi Pengaruh Besarnya Arus Listrik Terhadap Distribusi Kekerasan, Struktur Mikro, Dan Kekuatan Impak Pada Baja Karbon Rendah Jenis Sb 46. 2007.Jurnal Sains dan Teknologi EMAS, Vol. 17, No. 3, Agustus 2007. Jakarta

Suparno, Hariadi dan Imam, 2009. Perancangan Rangkaian Mesin Las Dengan Tenaga Baterai, Jurnal Mekanik Politeknik Negeri Samarinda, Vol.2 No.1 Januari 2009, hlm 51-55. Politeknik Negeri Samarinda

Wiryosumarto, H. dan Toshie Okumura, 2000. Teknologi Pengelasan Logam, cetakan kedelapan, Pradnya Paramita, Jakarta. 